\title{
THE RELATION OF HIPPURIC ACID EXCRETION TO THE VOLUME OF THE URINE ${ }^{1,2}$
}

\author{
By THOMAS E. MACHELLA, JOHN D. HELM, AND FRANCIS W. CHORNOCK \\ (From the Gastro-Intestinal Section (Kinsey-Thomas Foundation) of the Medical Clinic, \\ University of Pennsylvania Hospital, and the Biochemistry Laboratory \\ of the Philadelphia General Hospital, Philadelphia)
}

(Received for publication June 8, 1942)

The data submitted in this presentation indicate that the amount of benzoic acid excreted in the urine as hippuric acid in the Quick intravenous test (1) for liver function is influenced to a considerable extent by the volume of the simultaneous output of urine. This factor may account for some of the high values that at times have been observed in normal individuals, and even in patients with hepatic disease. The data also show a lack of correlation between body weight, bromsulphalein excretion, and the results of the Quick test.

Before Quick (2) introduced the hippuric acid test for liver function, it had been employed by Kingsbury and Swanson (3) and by Bryan (4) as a measure of renal function. Thus, for the proper interpretation of the test in liver disease, it would seem that adequate renal function should be present, because an impairment of the latter would depress the rate of excretion of the hippuric acid and so mimic hepatic dysfunction. Accordingly some workers have regarded, as a prerequisite for the proper interpretation of the test in hepatic disease, normal renal function, as judged by the urea clearance test or by the absence of a retention of blood urea nitrogen. Quick (5) believed, however, that the rate of hippuric acid excretion by the kidneys is 50 per cent higher than its rate of synthesis in the liver and that, as a result, only very serious disorders of renal function would affect its elimination in the urine. Thus it has been alleged that a normal excretion of hippuric acid can be obtained despite a greatly diminished urea clearance or an increased urea content of the blood $(6,7)$.

The effect of the volume of the output of the urine on the amount of hippuric acid eliminated

\footnotetext{
1 Presented before the American Federation for Clinical Research, April 20, 1942, Minneapolis, Minn.

2 Aided by a grant from the Smith, Kline and French Laboratories.
}

has received little attention, though Snapper and Grünbaum (8) noted that nephritic patients, having an abnormal retention of urea, may eliminate more hippuric acid in a large than in a small output of urine. Probstein and Londe (7), on the other hand, found no relation between urinary volume and the output of hippuric acid in 14 normal subjects.

A small excretion of hippuric acid, together with a small volume of urine, was observed in certain subjects in whom all other tests of hepatic function were negative. At first, this was thought to be due to incomplete evacuation of the bladder, but a similar result was obtained when we resorted to catheterization. Then, a very high value for hippuric acid excretion was observed in a patient who had a decompensated portal cirrhosis. He passed at the same time a very large volume of urine. He had a blood urea nitrogen concentration of $5 \mathrm{mgm}$. per cent, and it seemed probable that, in him, a simple diuresis was occurring. On the basis of these observations, we decided to determine whether or not any significant correlation could be established between the amount of the hippuric acid excreted and the simultaneous volume of the urine in our series of cases in which hippuric acid tests were being done.

Because Mateer (9) suggested that the size of the individual might influence the results of the test, we also examined for a correlation between body weight and the amount of hippuric acid excreted in the urine. We have included, in addition, data on the results of the bromsulphalein test because a difference of opinion (9 to 12) exists in the literature concerning the relative sensitivity of the bromsulphalein and the hippuric acid tests.

\section{DESCRIPTION OF SUBJECTS}

The hippuric acid test was performed on 100 patients in the medical and surgical wards or in the gastro- 
TABLE I

Data on 100 cases of evident or suspected hepatic disease

The high values for benzoic acid excretion in cases 1 and 2 were checked by duplicate analyses but cannot be explained at this time.

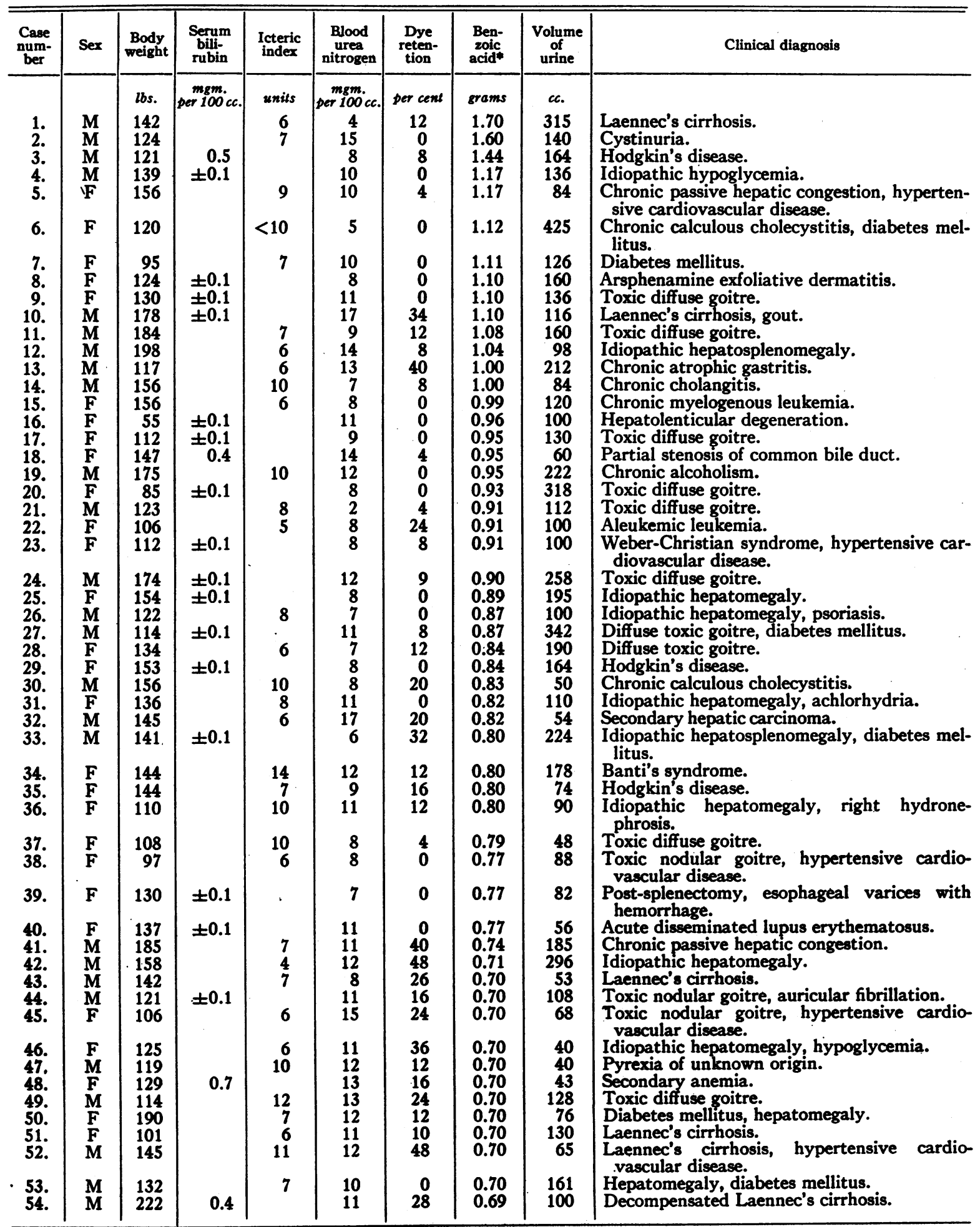


TABLE I-Continued

\begin{tabular}{|c|c|c|c|c|c|c|c|c|c|}
\hline $\begin{array}{c}\text { Case } \\
\text { num- } \\
\text { ber }\end{array}$ & Sex & $\begin{array}{c}\text { Body } \\
\text { weight }\end{array}$ & $\begin{array}{c}\text { Serum } \\
\text { bili- } \\
\text { rubin }\end{array}$ & $\begin{array}{l}\text { Icteric } \\
\text { index }\end{array}$ & $\underset{\substack{\text { Blood } \\
\text { urea } \\
\text { nitrogen }}}{\text {. }}$ & $\begin{array}{c}\text { Dye } \\
\text { reten- } \\
\text { tion }\end{array}$ & $\begin{array}{l}\text { Ben- } \\
\text { zoic } \\
\text { acid }\end{array}$ & $\begin{array}{c}\text { Volume } \\
\text { of } \\
\text { urine }\end{array}$ & Clinical diagnosis \\
\hline 55. & $\mathbf{F}$ & $\begin{array}{l}\text { lbs. } \\
103\end{array}$ & per 100 cc. & $\begin{array}{c}\text { units } \\
12\end{array}$ & $\begin{array}{l}\text { mgm. } \\
\operatorname{per} 100 \mathrm{ccc} \\
8\end{array}$ & $\begin{array}{l}\text { per cent } \\
12\end{array}$ & $\begin{array}{l}\text { grams } \\
0.68\end{array}$ & $\begin{array}{l}\text { cc. } \\
126\end{array}$ & Chronic calculous cholecystitis, diabetes $\mathrm{m}$ \\
\hline $\begin{array}{l}56 . \\
57 . \\
58 .\end{array}$ & $\begin{array}{l}\mathbf{F} \\
\mathbf{F}\end{array}$ & $\begin{array}{l}142 \\
123 \\
146\end{array}$ & $\begin{array}{l} \pm 0.1 \\
\pm 0.1 \\
\pm 0.1\end{array}$ & & $\begin{array}{r}7 \\
9 \\
13\end{array}$ & $\begin{array}{r}0 \\
12 \\
16\end{array}$ & $\begin{array}{l}0.68 \\
0.68 \\
0.68\end{array}$ & $\begin{array}{r}48 \\
100 \\
96\end{array}$ & $\begin{array}{l}\text { litus. } \\
\text { Hepatomegaly, exfoliative dermatitis. } \\
\text { Toxic diffuse goitre. } \\
\text { Toxic nodular goitre, chronic passive hepatic }\end{array}$ \\
\hline $\begin{array}{l}59 . \\
60 . \\
61 .\end{array}$ & $\begin{array}{l}\mathbf{M} \\
\mathbf{M}\end{array}$ & $\begin{array}{l}183 \\
136 \\
144\end{array}$ & & $\begin{array}{l}7 \\
6 \\
4\end{array}$ & $\begin{array}{r}8 \\
9 \\
17\end{array}$ & $\begin{array}{r}20 \\
0 \\
16\end{array}$ & $\begin{array}{l}0.68 \\
0.68 \\
0.68\end{array}$ & $\begin{array}{l}60 \\
95 \\
80\end{array}$ & $\begin{array}{l}\text { congestion. } \\
\text { Congenital hypoplasia of liver. } \\
\text { Idiopathic hypoglycemia. } \\
\text { Chronic calculous cholecystitis, secondary }\end{array}$ \\
\hline 62. & $\mathbf{F}$ & 220 & \pm 0.1 & & 12 & 20 & 0.66 & 48 & $\begin{array}{l}\text { Chremia. } \\
\text { litus. }\end{array}$ \\
\hline $\begin{array}{l}63 . \\
64 .\end{array}$ & $\stackrel{\mathbf{M}}{\mathbf{F}}$ & $\begin{array}{l}195 \\
160\end{array}$ & \pm 0.1 & 12 & $\begin{array}{r}11 \\
8\end{array}$ & $\begin{array}{l}8 \\
8\end{array}$ & $\begin{array}{l}0.64 \\
0.63\end{array}$ & $\begin{array}{l}52 \\
80\end{array}$ & $\begin{array}{l}\text { Polycythemia vera. } \\
\text { Toxic nodular goitre, auricular fibrillation, } \\
\text { chronic hepatic passive congestion. }\end{array}$ \\
\hline $\begin{array}{l}65 . \\
66 . \\
67 .\end{array}$ & $\begin{array}{l}\mathbf{M} \\
\mathbf{F}\end{array}$ & $\begin{array}{l}104 \\
144 \\
134\end{array}$ & \pm 0.1 & $\begin{array}{r}3 \\
14\end{array}$ & $\begin{array}{r}8 \\
12 \\
14\end{array}$ & $\begin{array}{r}0 \\
12 \\
48\end{array}$ & $\begin{array}{l}0.60 \\
0.60 \\
0.60\end{array}$ & $\begin{array}{l}45 \\
80 \\
84\end{array}$ & $\begin{array}{l}\text { Post-splenectomy, Banti's syndrome. } \\
\text { Banti's syndrome. } \\
\text { Chronic calculous cholecystitis, renal calculus, } \\
\text { pyelonephritis. }\end{array}$ \\
\hline $\begin{array}{l}68 . \\
69 . \\
70 . \\
71 . \\
72 . \\
73 .\end{array}$ & $\begin{array}{l}\mathbf{M} \\
\mathbf{F} \\
\mathbf{M} \\
\mathbf{M} \\
\mathbf{F}\end{array}$ & $\begin{array}{l}141 \\
106 \\
151 \\
182 \\
137 \\
130\end{array}$ & $\begin{array}{r}0.3 \\
0.4 \\
0.4 \\
\pm 0.1\end{array}$ & 14 & $\begin{array}{r}22 \\
10 \\
8 \\
15 \\
16\end{array}$ & $\begin{array}{r}32 \\
16 \\
16 \\
0 \\
36 \\
28\end{array}$ & $\begin{array}{l}0.60 \\
0.60 \\
0.60 \\
0.59 \\
0.56 \\
0.55\end{array}$ & $\begin{array}{c}174- \\
96 \\
80 \\
55 \\
200 \\
85\end{array}$ & $\begin{array}{l}\text { pyeionephritis. } \\
\text { Laennec's cirrhosis. } \\
\text { Chronic lymphocytic leukemia. } \\
\text { Chronic lymphocytic leukemia. } \\
\text { Idiopathic hepatomegaly. } \\
\text { Polyserositis. } \\
\text { Toxic nodular goitre, auricular. fibrillation, } \\
\text { chronic heoatic passive congestion. }\end{array}$ \\
\hline $\begin{array}{l}74 . \\
75 .\end{array}$ & $\underset{\mathbf{F}}{\mathbf{F}}$ & $\begin{array}{l}103 \\
131\end{array}$ & 0.1 & 8 & $\begin{array}{l}8 \\
8\end{array}$ & $\begin{array}{l}8 \\
8\end{array}$ & $\begin{array}{l}0.54 \\
0.54\end{array}$ & $\begin{array}{l}84 \\
84\end{array}$ & $\begin{array}{l}\text { Subacute bacterial endocarditis. } \\
\text { Chronic hepatic passive congestion, hyperten- } \\
\text { sive cardiovascular disease. }\end{array}$ \\
\hline $\begin{array}{l}76 . \\
77 .\end{array}$ & $\begin{array}{l}\mathbf{F} \\
\mathbf{F}\end{array}$ & $\begin{array}{l}148 \\
160\end{array}$ & 0.1 & 7 & $\begin{array}{r}8 \\
10\end{array}$ & $\begin{array}{l}36 \\
48\end{array}$ & $\begin{array}{l}0.54 \\
0.54\end{array}$ & $\begin{array}{l}43 \\
70\end{array}$ & $\begin{array}{l}\text { Chronic lymphocytic leukemia. } \\
\text { Toxic nodular goitre, auricular fibrillation, } \\
\text { chronic hepatic passive congestion. }\end{array}$ \\
\hline $\begin{array}{l}78 . \\
79 . \\
80 . \\
81 .\end{array}$ & $\begin{array}{l}\mathbf{M} \\
\mathbf{F} \\
\mathbf{M}\end{array}$ & $\begin{array}{l}132 \\
124 \\
142 \\
173\end{array}$ & \pm 0.1 & $\begin{array}{l}6 \\
8 \\
9\end{array}$ & $\begin{array}{l}19 \\
10 \\
15 \\
16\end{array}$ & $\begin{array}{r}12 \\
0 \\
15 \\
36\end{array}$ & $\begin{array}{l}0.50 \\
0.50 \\
0.50 \\
0.50\end{array}$ & $\begin{array}{r}140 \\
110 \\
64 \\
90\end{array}$ & $\begin{array}{l}\text { Laennec's cirrhosis. } \\
\text { Hodgkin's disease. } \\
\text { Laennec's cirrhosis. } \\
\text { Chronic passive. hepatic congestion, hyper- } \\
\text { tensive cardiovascular disease. }\end{array}$ \\
\hline 82. & $\mathbf{M}$ & 182 & & 9 & 19 & 24 & 0.50 & 202 & $\begin{array}{l}\text { Chronic passive hepatic congestion, hyperten- } \\
\text { sive cardiovascular disease. }\end{array}$ \\
\hline $\begin{array}{l}83 . \\
84 .\end{array}$ & $\begin{array}{l}\mathbf{F} \\
\mathbf{F}\end{array}$ & $\begin{array}{r}90 \\
115\end{array}$ & \pm 0.1 & 6 & $\begin{array}{r}9 \\
17\end{array}$ & $\begin{array}{r}0 \\
14\end{array}$ & $\begin{array}{l}0.50 \\
0.48\end{array}$ & $\begin{array}{r}200 \\
34\end{array}$ & $\begin{array}{l}\text { Toxic diffuse goitre. } \\
\text { Chronic passive hepatic congestion, luetic } \\
\text { cardiovascular disease. }\end{array}$ \\
\hline 85. & F & 111 & \pm 0.1 & & 16 & 16 & 0.48 & 156 & $\begin{array}{l}\text { Primary anemia, diabetes mellitus, toxic } \\
\text { nodular goitre. }\end{array}$ \\
\hline $\begin{array}{l}86 . \\
87 . \\
88 . \\
89 .\end{array}$ & $\begin{array}{l}\mathbf{F} \\
\mathbf{F} \\
\mathbf{F}\end{array}$ & $\begin{array}{r}86 \\
125 \\
100 \\
155\end{array}$ & $\begin{array}{l} \pm 0.1 \\
\pm 0.1\end{array}$ & $\begin{array}{l}4 \\
7\end{array}$ & $\begin{array}{r}16 \\
9 \\
13 \\
14\end{array}$ & $\begin{array}{r}0 \\
0 \\
5 \\
16\end{array}$ & $\begin{array}{l}0.44 \\
0.41 \\
0.40 \\
0.40\end{array}$ & $\begin{array}{r}90 \\
100 \\
86 \\
36\end{array}$ & $\begin{array}{l}\text { Scurvy. } \\
\text { Xanthomatosis. } \\
\text { Diffuse toxic goitre. } \\
\text { Diffuse toxic goitre, hypertensive cardiovas- } \\
\text { cular disease. }\end{array}$ \\
\hline $\begin{array}{l}90 . \\
91 . \\
92 .\end{array}$ & $\begin{array}{l}\mathbf{F} \\
\mathbf{M}\end{array}$ & $\begin{array}{l}121 \\
105 \\
145\end{array}$ & & $\begin{array}{r}6 \\
7 \\
11\end{array}$ & $\begin{array}{l}14 \\
12 \\
12\end{array}$ & $\begin{array}{l}24 \\
12 \\
48\end{array}$ & $\begin{array}{l}0.36 \\
0.33 \\
0.32\end{array}$ & $\begin{array}{r}226 \\
50 \\
65\end{array}$ & $\begin{array}{l}\text { Primary anemia. } \\
\text { Idiopathic hepatomegaly, scurvy. } \\
\text { Laennec's cirrhosis, hypertensive cardiovascu- } \\
\text { lar disease. }\end{array}$ \\
\hline $\begin{array}{l}93 . \\
94 .\end{array}$ & $\underset{F}{F}$ & $\begin{array}{l}135 \\
130\end{array}$ & \pm 0.1 & 5 & $\begin{array}{l}13 \\
15\end{array}$ & $\begin{array}{l}20 \\
32\end{array}$ & $\begin{array}{l}0.32 \\
0.30\end{array}$ & 75 & $\begin{array}{l}\text { Multiple cystic disease of the liver. } \\
\text { Diffuse toxic goitre, chronic passive hepatic } \\
\text { congestion. }\end{array}$ \\
\hline $\begin{array}{l}95 . \\
96 .\end{array}$ & $\begin{array}{l}\mathbf{F} \\
\mathbf{M}\end{array}$ & $\begin{array}{l}139 \\
110\end{array}$ & \pm 0.1 & 9 & $\begin{array}{l}11 \\
21\end{array}$ & $\begin{array}{r}36 \\
8\end{array}$ & $\begin{array}{l}0.24 \\
0.25\end{array}$ & $\begin{array}{l}48 \\
80\end{array}$ & $\begin{array}{l}\text { Congenital cystic disease of the liver. } \\
\text { Toxic nodular goitre, hypertensive cardio- } \\
\text { vascular disease. }\end{array}$ \\
\hline 97. & $\mathbf{F}$ & 95 & & 11 & 10 & 0 & 0.22 & 84 & $\begin{array}{l}\text { Chronic passive hepatic congestion, malignant } \\
\text { hypertension. . }\end{array}$ \\
\hline 98. & $\mathbf{F}$ & 85 & & 4 & 9 & 4 & 0.18 & 42 & $\begin{array}{l}\text { Chronic passive hepatic congestion, hyper- } \\
\text { tensive cardiovascular disease, toxic nodular } \\
\text { goitre. }\end{array}$ \\
\hline $\begin{array}{c}99 . \\
100 .\end{array}$ & $\underset{\mathbf{F}}{\mathbf{F}}$ & $\begin{array}{l}243 \\
102\end{array}$ & & $\begin{array}{l}7 \\
9\end{array}$ & $\begin{array}{l}8 \\
9\end{array}$ & $\begin{array}{l}32 \\
36\end{array}$ & $\begin{array}{l}0.14 \\
0.11\end{array}$ & $\begin{array}{l}15 \\
20\end{array}$ & $\begin{array}{l}\text { Chronic pancreatitis, diabetes mellitus. } \\
\text { Chronic passive hepatic congestion, toxic } \\
\text { nodular goitre, hypertensive cardiovascular } \\
\text { disease. }\end{array}$ \\
\hline
\end{tabular}


intestinal clinic of the University of Pennsylvania Hospital. In all of them, hepatic disease was manifest or suspected, either because the liver was significantly enlarged or because the patient had a disease in which hepatic dysfunction may occur (Table I). In each case, the blood urea nitrogen concentration was normal and the direct van den Bergh reaction, negative. The body weight, serum bilirubin or icteric index, and the presence or absence of retention of bromsulphalein in the blood serum one half hour after its injection were determined in all instances.

In 12 other subjects (all females), a comparative study of the hippuric acid test, performed in the usual fashion, and after giving an excess of water to increase urine volume, was made (Figure 1). Five of these (Cases 1, $2,3,4,5)$ were apparently normal individuals and had a negative direct van den Bergh reaction, a normal serum bilirubin level, no retention of bromsulphalein in the blood serum after one half hour, and a negative hippuric acid test. One (Case 6), with chronic glomerulonephritis, had an elevated blood urea nitrogen value $(62 \mathrm{mgm}$. per cent), a urea clearance of 20 per cent and negative van den Bergh and bromsulphalein tests. Three patients (Cases 7, 8, and 9) had some retention of bromsulphalein (4, 10 and 16 per cent), their direct van den Bergh reactions being negative or delayed, and their diagnoses being respectively non-toxic nodular goitre, diabetes mellitus with peripheral neuritis, and diffuse toxic goitre.

\section{SODIUM BENZOATE}

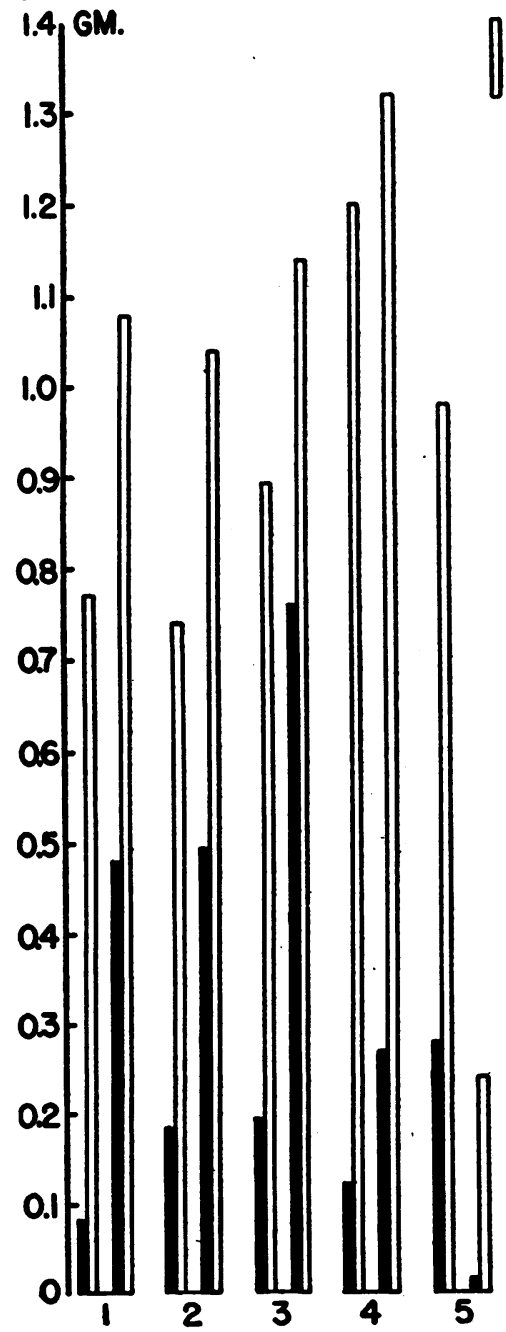

SODIUM BENZOATE
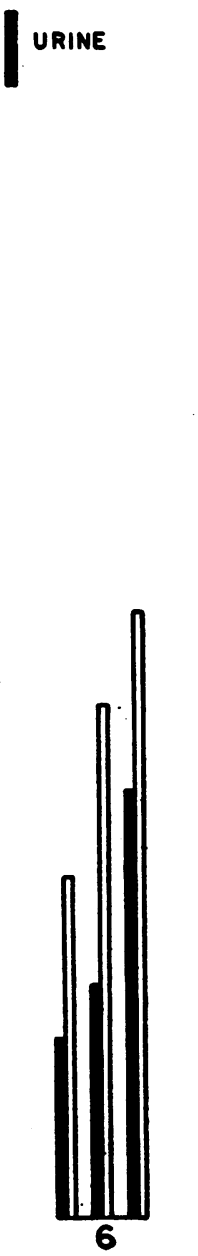

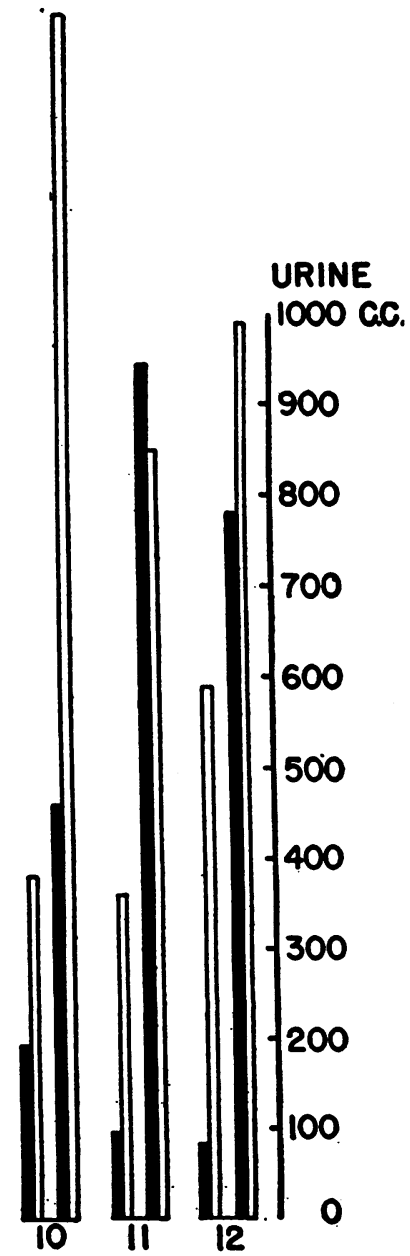

Fig. 1. Comparison of Results of the Hippuric Acid Test When Performed Without Control of the Fluid Intake and When the Flutd Intake Was Purposely Increased

The first pair of columns in each case represents the volume of urine and the amount of hippuric acid, in terms of benzoic acid, excreted during the test when performed under the usual conditions; the second pair, the results when the fluid intake was increased.

Erratum: Measurements are of benzoic acid, not sodium benzoate, in this and the following figures. 
Case 10, an acromegalic, manifested a biphasic direct van den Bergh reaction, a slight elevation of the serum bilirubin ( $0.6 \mathrm{mgm}$. per cent), and a low value for hippuric acid excretion. The remaining 2 patients (Cases 11 and 12) were deeply jaundiced, had immediate direct van den Bergh reactions, very high icteric indices (66 and 112), and low values for hippuric acid excretion. The diagnoses in these 2 patients were biliary cirrhosis (Case 11) and acute catarrhal jaundice (Case 12).

\section{METHODS}

The intravenous 1 hour hippuric acid test was performed by the method of Quick (1) with modifications proposed by Weichselbaum and Probstein (13). The amount of hippuric acid in the urine was determined by titration with sodium hydroxide. One hour after a breakfast of 1 cup of coffee and 2 slices of toast, the patient was instructed to empty the bladder completely. Immediately thereafter, $20 \mathrm{cc}$. of an 8.85 per cent solution of sodium benzoate (1.77 grams) were injected intravenously, the duration of time for the injection being 5 minutes. One glass of water $(180 \mathrm{cc}$.) was then ingested. One hour following the completion of the injection of the benzoate solution, the bladder was emptied by catheterization in all females (62) and in all those males (6) who could not assume the erect posture to void. The remaining 32 males emptied their bladders by voiding and had no evidence of prostatism.

The bromsulphalein test was performed either on the day before or on the day after the hippuric acid test. The amount of dye used was $5 \mathrm{mgm}$. per kilogram of body weight, a single sample of venous blood being removed from the opposite arm 30 minutes after injection of the dye. The presence of any dye in the serum at the end of this time was considered as indicative of impaired excretory ability of the liver (14). The patients were required to be in the fasting state on the morning of the test. The icteric index, blood urea nitrogen, and serum bilirubin determinations were made by accepted standard routine laboratory procedures.

In those patients in whom we wished to determine the effect of water diuresis on the excretion of the hippuric acid, $360 \mathrm{cc}$. of water were administered $11 / 2$ and $1 / 2$ hours before the injection of the sodium benzoate, as well as immediately afterward. Thus, these patients received a total of $1080 \mathrm{cc}$. of water in addition to the fluid in the cup of coffee and the $20 \mathrm{cc}$. of sodium benzoate solution injected intravenously. The bladders in all of these patients were completely emptied by catheterization 1 hour after the end of the injection of the sodium benzoate solution.

\section{RESULTS}

\section{A. Relation of hippuric acid excretion to body weight}

No significant correlation between the amount of benzoic acid excreted as hippuric acid and the body weight of the subjects was found (Figure $2)$. The correlation coefficient $(r)$ was +0.074 .

\section{B. Relation of hippuric acid excretion to the vol- ume of urine}

In the 100 cases included in Table I, a direct correlation existed between the amount of hippuric acid eliminated through the kidneys and the volume of the urine secreted in the same period. When the range of hippuric acid excreted, in terms of benzoic acid, was divided into 5 groups in the order of increasing values, the average volume of the urine in the particular groups increased directly (Table II). This relationship was found to be mathematically significant when the values were plotted against urinary volume in all of the tests (194) performed in the clinic to date (Figure 3 ). The subjects included normals as well as persons with evident or suspected hepatic disease. The correlation coefficient $(r)$ was +0.480 .

\section{Effect of increasing the urinary volume on the amount of hippuric acid excreted}

The urinary output and, at the same time, the amount of excreted hippuric acid were increased in 10 of the 12 patients in whom on a second test the fluid intake was increased (Figure 1). In 4 of the 5 control subjects (Cases 1, 2, 3, 4), the volume of urine was increased from an average of 146 to $501 \mathrm{cc}$., while the average benzoic acid excretion was increased from 0.9 to 1.14 grams. In 2 of the subjects, 1 a control (Case 5) and 1 with mild hepatic damage (Case 8), there was a decrease in the volume of urine as well as in the amount of benzoic acid. Both of these subjects complained of intense nausea during and after the period when large amounts of water were being ingested. The 3 patients with bilirubinemia and dye retention (Cases 10, 11 and 12) had subnormal values for benzoic acid excretion when the test was performed by the standard technique. In all of them, the benzoic acid excretion was increased to normal or above by inducing a water diuresis. In Case 6 , with a urea nitrogen retention of 62 , the benzoic acid excretion increased from 0.38 to 0.57 and then to 0.67 gram as the urine volume increased from 200 to 260 and finally to $475 \mathrm{cc}$. (Figure 1). 


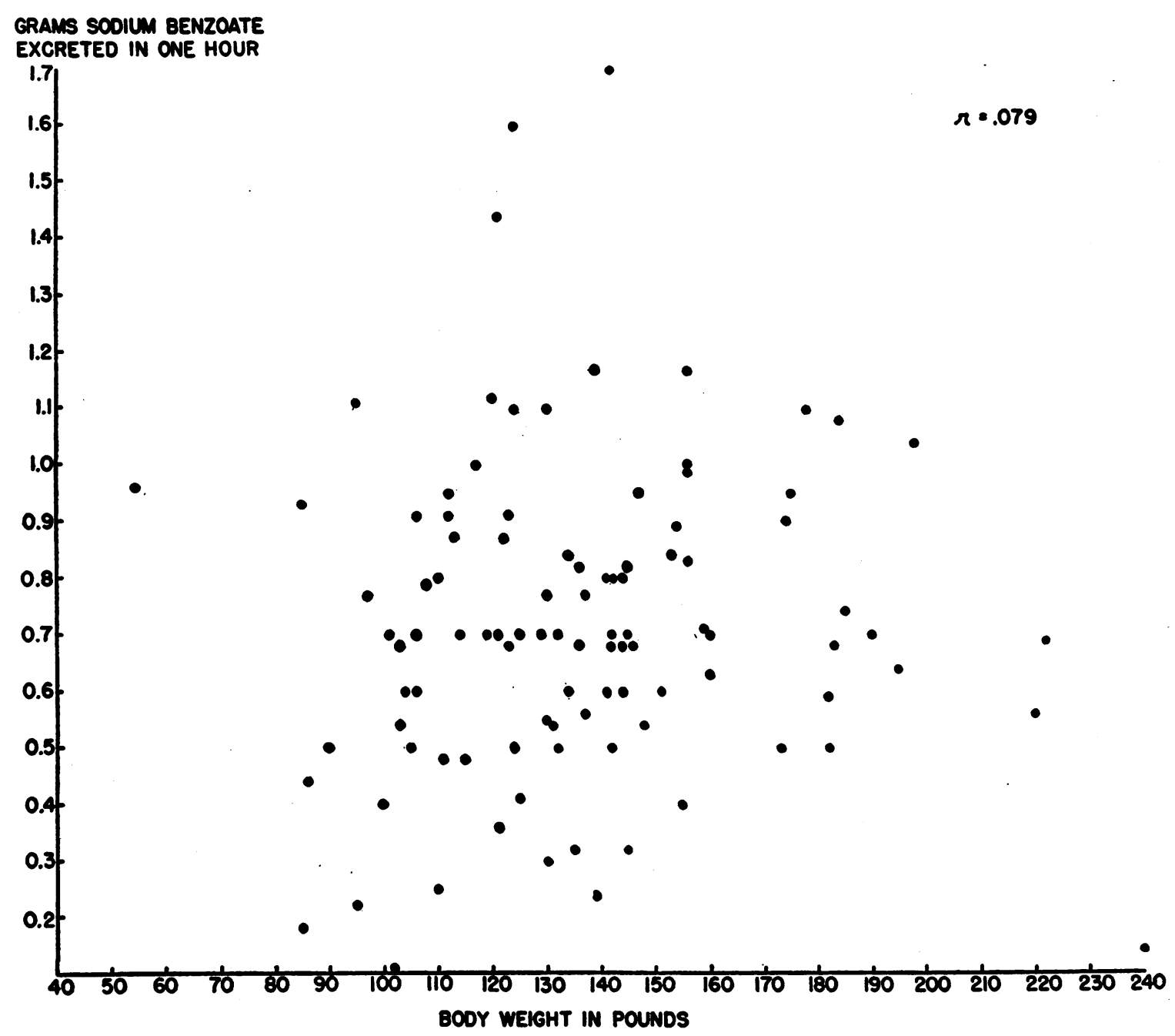

Fig. 2. The Relation of Body Weight to the Amount of Hippuric Acid Excreted, in Terms of BenzoIc Acid

Correlation coefficient, $(r) \quad 0.079$, is not significant.

D. Relation of hippuric acid excretion to the presence or absence of bromsulphalein retention

In the 100 cases with a negative direct van den Bergh reaction, the excretion of hippuric acid was below normal in 47 , while bromsulphalein retention was present in 72 . Both tests were positive in 38 cases and negative in 19. The dye test was positive and the hippuric acid test negative in 34, while the reverse was true in 9 (Table III). In 16 of the cases, the benzoic acid excretion was greater than the upper normal of 0.95 gram, yet in 8 of these, dye retention was present (Table I). In some series of cases studied by other authors (9), the hippuric acid test has been observed to be more sensitive than the bromsulphalein test.

\section{COM MENT}

The data herein presented indicate that, irrespective of the ability of the body to synthesize hippuric acid, its elimination through the kidneys is influenced by the volume of the urine secreted during the test period. The ability to influence the amount of hippuric acid excreted in individual subjects by varying the volume of their urine, incident to the administration of fluid, strongly supports the correlation in the data on single 
tests which we have presented. This relationship between the volume of the urine and the amount of hippuric acid excreted presents some objection to the use of hippuric acid elimination as a test for hepatic function, unless correction can be made for variations in urinary volume.

Possibly this relationship may account for some of the high values for the test observed by Mateer (9) in some of his controls, and for the higher than normal values observed by Rosenberg (15) in some patients with hepatic disease, and attributed by him to a hyperirritable phase of damage.

The low values for the 2 subjects (Cases 5,8 ) in whom we failed to induce a water diuresis deserve brief comment. The subjects drank the fluid, and none of the urine was lost. Both of them were extremely nauseated during the test. The low urine volume outputs could perhaps be explained on the basis of failure of the fluid to leave the stomach and so reach the intestine for absorption because of duodenal spasm, which, according to Ingelfinger (16), may occur during nausea.

The attempt to find the one most sensitive test of impaired hepatic function has led to conflicting results and views. In some series of cases (9) impaired hippuric acid excretion has been more frequent than retention of bromsulphalein. In our series, the reverse was the case. After making due allowance for such factors as the influ-

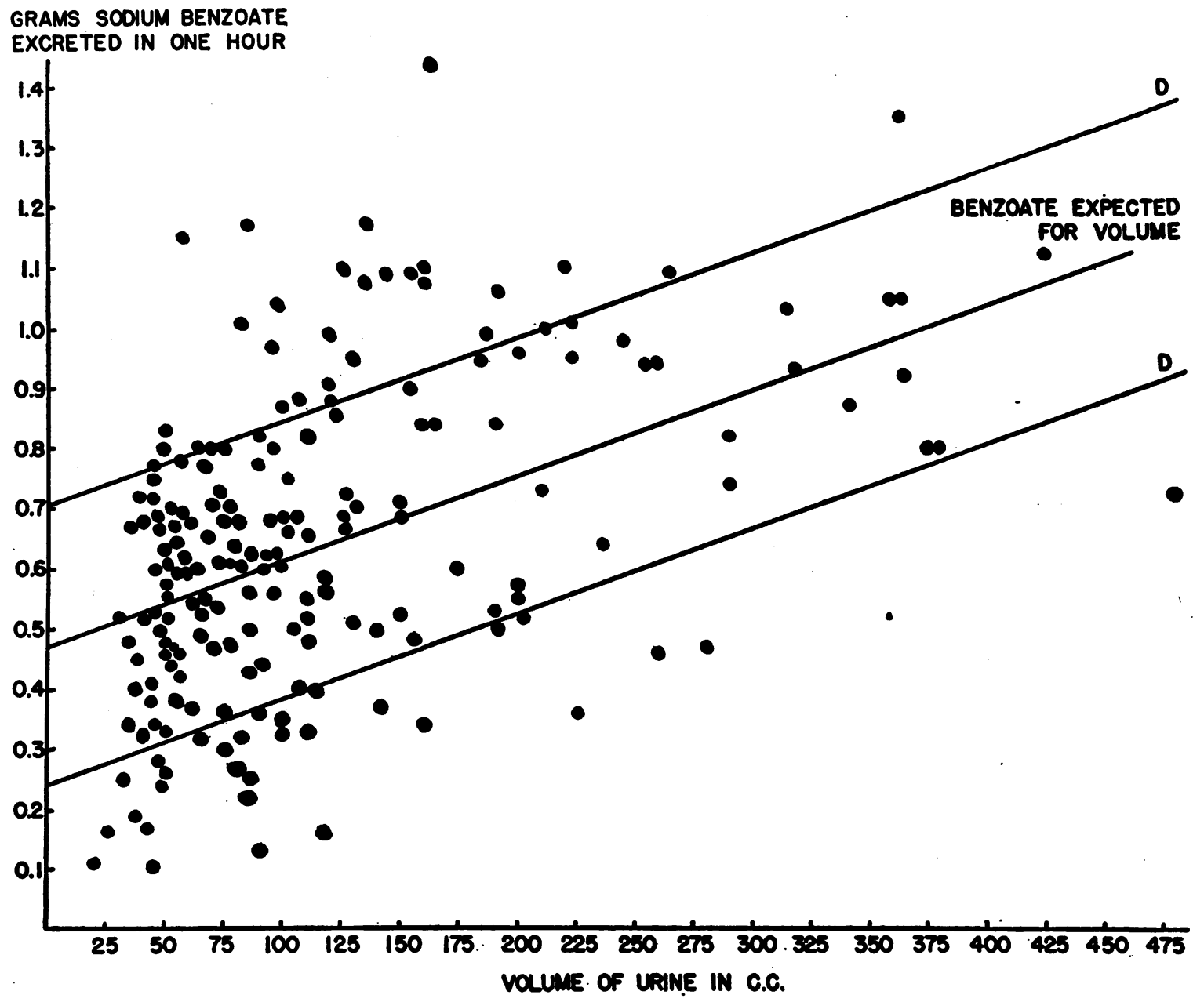

Fig. 3. The Relation of Volume of Urine to the Amount of Hippuric Acid, Excreted as Benzoic Acid, in 194 Cases of Evident or Suspected Hepatic Disease

The correlation coefficient $(r)+0.480$, is significant.

$D$ indicates standard deviation. 
TABLE II

The relation of the average volume of urine eliminated during the test period to the amount of hippuric acid excreted, in terms of bensoic acid

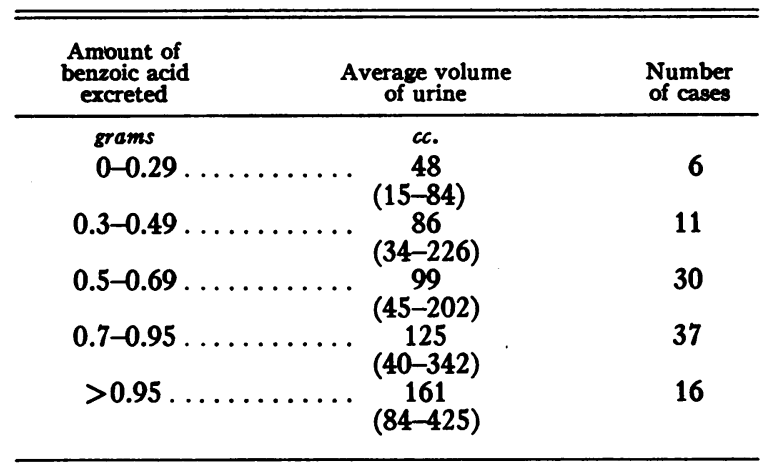

ence of urine volume output, impairment of renal excretion, and variation of technique, there still remain differences from case to case as to which test first exhibits impairment. The use of several tests of hepatic function will, therefore, reveal an early disturbance of function more often than will any single test.

TABLE III

Summary of results on 100 hippuric acid and bromsulphalein tests

\begin{tabular}{ccc}
\hline \hline $\begin{array}{c}\text { Impaired } \\
\text { hippuric acid } \\
\text { synthesis }\end{array}$ & $\begin{array}{c}\text { Retention } \\
\text { of dye }\end{array}$ & $\begin{array}{c}\text { Number } \\
\text { of cases }\end{array}$ \\
\hline+ & + & 38 \\
+ & 0 & 9 \\
0 & + & 34 \\
0 & 0 & 19 \\
\hline
\end{tabular}

The dye test is almost always positive when an impairment of hepatic excretory ability is already indicated by an immediate or biphasic direct van den Bergh reaction. It is for this reason that we required that the direct van den Bergh test be negative in each of the 100 cases in which the results of the dye and the hippuric acid test were to be compared.

\section{SUMMARY}

In a series of 100 patients with manifest or suspected hepatic disease, a significant direct correlation was found between the amount of hippuric acid eliminated by the kidneys and the volume of the urine secreted during the same period. A higher than normal value for benzoic acid excretion was associated with a large volume of urine. A low value in some patients with hepatic disease could be increased to normal or above by inducing a water diuresis. A low value for benzoic acid excretion in one patient with excessive blood urea nitrogen retention was raised almost to normal by a similar procedure. The dependence of the hippuric acid test on the rate of that substance's excretion by the kidneys constitutes some objection to its use as an index of the detoxifying ability of the liver.

Bromsulphalein retention occurred in a higher percentage of our cases than did an impaired hippuric acid excretion.

The authors are indebted to Dr. J. H. Austin, Professor of Research Medicine, University of Pennsylvania Medical School, for the statistical analyses of the data, and to Dr. J. G. Reinhold for the use of facilities in the Biochemistry Laboratory of the Philadelphia General Hospital.

\section{BIBLIOGRAPHY}

1. Quick, A. J., Ottenstein, H. N., and Weltchek, H., Synthesis of hippuric acid in man following intravenous injection of sodium benzoate. Proc. Soc. Exper. Biol. and Med., 1938, 38, 77.

2. Quick, A. J., The synthesis of hippuric acid: A new test of liver function. Am. J. M. Sc., 1933, 185, 630.

3. Kingsbury, F. B., and Swanson, W. W., Synthesis and elimination of hippuric acid in nephritis: A new renal function test. Arch. Int. Med., 1921, 28, 220.

4. Bryan, A. W., Clinical and experimental studies on sodium benzoate: Value of sodium benzoate test of renal function, and the effect of injury of liver on hippuric acid synthesis. J. Clin. Invest., $1925,2,1$.

5. Quick, A. J., Clinical value of the test for hippuric acid in cases of disease of the liver. Arch. Int. Med., 1936, 57, 544.

6. Fouts, P. J., Helmer, O. M., and Zerfas, L. G., The secretion of hippuric acid in pernicious anemia. Am. J. M. Sc., 1937, 193, 647.

7. Probstein, J. G., and Londe, S., Studies of liver function by means of Quick's hippuric acid test. Ann. Surg., 1940, 111, 230.

8. Snapper, J., and Grünbaum, A., Der hippursaurestoff wechsel bei nierkrankheiten. Klin. Wchnschr., 1924, 3, 101.

9. Mateer, J. G., Baltz, J. I., Marion, D. F., and Hollands, R. A., A comparative evaluation of the newer liver function tests. Am. J. Digest. Dis., 1942, 9, 1.

10. Boyce, F. F., and McFetridge, E. M., Studies of hepatic function by the Quick hippuric acid test. 
III. Various surgical states. Arch. Surg., 1938, 37, 443.

11. De Lor, C. J., and Reinhart, H. L., Analysis of hippuric acid, galactose tolerance, bromsulphthalein and prothrombin tests in 381 cases. Am. J. Clin. Path., 1940, 10, 617.

12. White, F. W., Deutsch, E., and Maddock, S., The comparison of serial hippuric acid excretion, total cholesterol, cholesterol ester and phospho-lipid tests in diseases of the liver. A clinical comparison of the tests. Am. J. Digest. Dis., 1940, 7, 3.

13. Weichselbaum, T. E., and Probstein, J. G., Determination of hippuric acid in urine. J. Lab. and Clin. Med., 1939, 24, 636.
14. Helm, J. D., and Machella, T. E., The significance of dosage and time factors on the value of the bromsulphalein test for liver function. Am. J. Digest. Dis., 1942, 9, 141.

15. Rosenberg, D. I., Discussion of paper by Mateer (9). 16. Ingelfinger, F. J., and Moss, R. E., The activity of the descending duodenum in man during nausea produced by caloric stimulation of the semicircular canals. Proc. Am. Physiol. Soc., 1942, $1,43$.

17. Miller, T. G., and Machella, T. E., Diseases of the liver. Nelson Loose Leaf Med., Thomas Nelson and Sons, New York, 1941, 5, 479. 